ISSN 2080-1653

DOI 10.24917/20801653.324.16

\author{
ZBigniew ZioŁo \\ Podkarpacka HE School of Bl. W. Findysz in Jasło, Poland \\ Pedagogical University of Cracow, Poland
}

\title{
Proposal for a Holistic Concept of Research into the Functioning of an Enterprise and Industry
}

\begin{abstract}
In the process of shaping particular academic disciplines, there is a need to synthesise the existing research results and on their basis propose new methodological approaches and indicate the possibility of applying new directions of theoretic-cognitive and application research. This is the idea to which the theme and purpose of this paper refers. It proposes a new holistic research concept. The first part of the article reviews the hitherto research problems concerning the operation of an industrial plant (enterprise). Presented are the changing research concepts that initially treated the industrial plant as a landscape element, and then as a production plant affecting the processes of industry concentration, as well as socio-economic and cultural changes of the surroundings. In the second part, in the light of the theory of the dynamic system, the assumption was made that an industrial enterprise is not an isolated element of geographical space, but one of its functional components. Its role changes under the influence of endogenous and exogenous factors, as well as in the process of civilisation development. Using the idea of a dynamic system and the model of the functioning of geographical space, a new, holistic concept of research into the operation and development of an industrial enterprise is proposed. It includes various relationships: between the enterprise and the elements of geographical space (natural, socio-economic, cultural), between the rules of economic development, between different functional types of enterprises, competitive, between the categories of the environment, between the power elites and types of policies. The proposed model approach makes it possible to define various relations with the enterprise and allows for a comprehensive understanding of its functioning in a diversified surroundings, and it provides for the definition of a more precise strategy for its development.
\end{abstract}

Keywords: conditions for the development of enterprises; industrial company; industrial plant; spatial structure of industry

Received: 15 July 2018

Accepted: 15 August 2018

\section{Suggested citation:}

Zioło, Z. (2018). Proposal for a Holistic Concept of Research into the Functioning of an Enterprise and Industry. Prace Komisji Geografii Przemysłu Polskiego Towarzystwa Geograficznego [Studies of the Industrial Geography Commission of the Polish Geographical Society], 32(4), 252-270. https://doi.org/10.24917/20801653.324.16 


\section{INTRODUCTION}

The 100th Anniversary of the Polish Geographical Society is an excellent opportunity to summarise the research achievements of individual geographical sciences, including geography of industry, but also to try to synthesise the current research achievements and present new analytical concepts that allow for more and more precise understanding of the processes shaping the geographical space. Proposals for further development and undertaking new research issues should refer to the changing conditions caused by the increasing progress of civilisation development, which in the geographical space affects the spatial polarisation of economic life and capital polarisation of the industry.

In the process of the development of geography, including geography of industry, similarly as in the process of development of individual scientific disciplines, there are subsequent stages associated with the pursuit of more and more precise understanding of the formation of geographical space and the way its essential elements function in it. It manifests itself in shifting from describing the object of cognition to explaining the process of its development, elaborating new concepts of developing models, defining development goals, improving research and verifying the methods of the accepted hypotheses, which then enable the construction of a theory.

Understanding the transformation processes of spatial structures is an essential premise for controlling development processes to increase the level and quality of life of the society. It becomes entirely possible thanks to a precise understanding of the conditions of the formation of the elements and relations that occur between them, which allow us to learn the laws (rules) that govern them. The rational management of the processes of change is the more effective, the more it is based on precisely justified theorems regarding the determination of the variability of the intensity of factors affecting the operations of change and the change of the potential. It is assumed that a set of views concerning a given field only then deserves to be called science, when there are fundamental theorems in it that allow justifying the derived assumptions (Domański, 1965 ,2018). Such ordered sets of views create a theory that, among others in the field of geography of industry, can be expressed in the convention of the formation of dynamic systems (Zioło, 1976, 1987, 2008, Zioło, Rachwał, 2008).

It can be assumed that the future of geography of industry, as well as other scientific disciplines, depends in no small extent on the importance of the scientific problems solved by them (theoretical and application). Addressing them is necessary for the methodological development not only of geography of industry but also of the related disciplines which are interested in the geographical space or its selected elements, such as industrial enterprises. In addition to the theoretical and cognitive problems, the development of geography of industry is mostly connected with the possibilities of applying its research results in economic practice. It is done mainly by providing theoretically justified and empirically verified patterns that allow making rational decisions, implementing specific spatial policy objectives, assessing them and forecasting future transformation processes. Generally, it should be assumed that the role of geography of industry is related to its contribution to solving the theoretical, cognitive and socially critical scientific problems resulting from the transformations in the spatial structure of industry. The effectiveness of the proposed solutions depends to a large extent on the proper diagnosis, verification of the assumed development goals and precision of the developed research methods. 
Therefore, there is a need for continuous work on the analysis of the variability of conditions for the development of industrial enterprises. It results not only from the pursuit of intensification of basic research but also from social needs, as well as the needs of management bodies which use the results of scientific studies for application purposes, e.g. building strategies for the development of local, regional and national systems, as well as understanding of the changing conditions taking place in the European and global space. Starting from the above assumptions, the subject of these considerations is the attempt to outline a proposal for a holistic concept of research into the functioning of an industrial enterprise as an essential element of the spatial structure of industry and national economy.

\section{OUTLINE OF THE REVIEW OF RESEARCH PROBLEMS OF AN INDUSTRIAL ENTERPRISE}

Theoretical concepts and research related to geography of industry regarding the transformation processes of the spatial structure of industry treat industrial enterprises (industrial plants) as their essential structural elements. Depending on the variability of their technical and economic potential, they affect the spatial layout of industry, its potential, branch and size structures. The concept of "spatial structure of industry" was introduced to Polish geographical literature by K. Dziewoński (1949), when dealing with issues of the production complex in the theory of location and planning practice. On the other hand, A. Kukliński (1959), considering this concept, stated that it was superior to the notions of "distribution of industry" and "location of industry".

We can treat the spatial structure of industry as "the totality of relationships between its elements". This concept assumes the existence of structural elements and their relations within a given set. K. Secomski (1956) and P.S. Florencea (1965), giving examples of various types of industrial structures, assume that the essential elements of the spatial arrangement of industry are industrial plants (enterprises). Their relations define the totality of relationships between the enterprises and plants regarding production and technology, economics, capital and market (Zioło, 1971, 1987, 1997).

In the light of these considerations, the term "spatial structure of industry" will be understood as one of the objective subspaces and part of the general socio-economic space characterised by a set of industrial plants (enterprises), the development of which is based on the intensity of technical, production, economic and infrastructural ties. These plants tend to cluster spatially, and - depending on their industrial potential and interrelationships - in the spatial structure of industry form specific sets, called spatial arrangements of industry concentration. This allows treating the spatial structure of industry as one of the elements of the socio-economic space, which in turn is an element of a more complex geographical space (Zioło, 1987, 1996, 2008).

In the process of developing geography of industry, the research issues of an industrial plant have changed. W. Ormicki (1934) treated the industrial plant as an element of the landscape. P. Stiepanow (1955), presenting the problems of research of an industrial plant, ascribed great importance to morphological analysis, which aimed to establish connections between the plant and the surrounding economic and natural environment. A. Kukliński (1954) and I. Fierla (1958) developed the concept of research of an industrial plant on the basis of technological, economic and location issues, as well as its connection with economic and geographical issues. The discussion on the problems 
of research on a single plant was undertaken by M.S. Zawadzki (1962). He defined an industrial plant as the primary spatial unit of industrial production. The plant focused on the interdependencies between output and space, which made it difficult to find the right research goals and methods. They were mainly based on the separation of economic objectives and methods, as well as methods in the field of economic geography. He defined the geographer's competencies in solving problems relating to shaping the spatial conditions for the creation and development of an industrial plant, the interaction of the plant and industrial center, the plant's position in the region's economic and spatial structure and in a given branch of industry, and establishing the relationship between the economic activity of the plant and the local conditions of the geographical environment. B. Winiarski (1962) expressed some doubt about the ordering of the above problems. According to him, more attention should be paid to its functions in the scope of reconstruction of the socio-economic structure of the surroundings. I. Fierla (1962) assumed that in the research of an industrial plant, the sales, supply, production cooperation and linking of the plant to the region should be taken as an essential issue. An important role was also attributed to the research on the plant's links in the field of the workforce and the ongoing socio-occupational changes in its environment (Turczyn, 1968; Turczyn-Zioło, 1978). M. Dobrowolska (1965) took the position that - depending on the research objectives - the plant should be treated not as a fundamental element of the spatial structure of industry, but also as a primary element of the socio-economic space. Referring to methodological issues, she stated that the right way of geographical thinking led from the analysis of the work and production workshop to the analysis of the centre and the industrial area. The above thesis was reflected in the studies of "Her School of Science" (Pakuła, 1960, 1965). A certain summary of the research problem of geography of industry was presented by L. Pakuła (1967), who included the "Questionnaire for industrial plant research", in which, as the subject of geographical research, the following issues were taken into consideration: location issues, development history, issues of labour force, process of work mechanisation, production issues, factory supply in raw materials etc., product sales, technological process, production costs, positive and negative impact of the plant on the area and development prospects. The questionnaire of L. Pakuła was developed for didactic work by M. Troc (1991a, 1991b), who then adapted it to research of the agri-food industry plant. T. Rachwał (2008), using the rich literature of the subject and taking into account the change in the behaviour of industrial enterprises in the new conditions of management, developed a new questionnaire on the company's research. It included: general characteristics of the company, its location, development process in a historical perspective, characteristics of a strategic investor, linking of a foreign strategic investor with the enterprise, issues of employment relationships, size and range of production, technological process and quality of production, procurement of materials and services, sales, changes in the level and structure of costs, profitability of production, financial results, positive and negative impact on the surroundings, evaluation of the current change process and the company's development prospects.

In reference to the emerging trends of changes in the management system, an attempt was made to determine the research issues of the industrial plant as part of the studies of the Methodological Center for Teacher Studies (Zioło, 1988a). As part of the development of methodological concepts, the following were presented: new theoretical approach to the functioning and development of an industrial enterprise (Zioło, 
1988b), the problems of locating industrial plants (Fierla, 1987, 1988, 1994a, 1994b), the location of plants and environmental protection (Dziadek, 1988), issues of labour force and employment (Turczyn, 1968; Turczyn-Zioło 1978; Ohme, 1988; Soja, 1988), production-spatial connections of an industrial plant (Troc, 1988), linking the plant with the elements of technical infrastructure (Makieła, 1988), as well as the themes of an industrial plant in geography teaching in primary and secondary school (Piskorz, 1988) and others.

Along with the changes in the management system, the conditions of socio-economic development have changed and new problems related to the functioning and development of industrial enterprises appeared (Zioło, 1994a; Domański, 1997). To a large extent, they also referred to the Report of the Commission for the Dynamics of Industry and Industrial Space of the International Geographical Union (Stryjakiewicz, 1994). They mainly concerned changes in the management system and the environment of industrial enterprises in new management conditions (Zioło, 1994b; Parysek, 1994; Kuciński, 1994, 2006, 2009; Pączka, 1994; Rachwał, 2003). Attempts have also been made to identify changes in empirical research, including: the possibilities of using the experience of the capitalist economy in creating a new order in the Łódź region (Niżnik, Riley, 1994), transforming the Toruń-Pacific Company LTD (Rochnowski, 1994), privatising (Matykowski, Szulc, 1994; Kozysa, Miszczuk, Żuk, 1994; Tobolska, 1994) and restructuring of enterprises (Rachwał, 2006), changes in the functioning of Słupsk industrial plants (Jażewicz, Rydz, 1994), meat plants (Adamczak, 1994; Rachwał, 2001a), electronic industry plants (Rachwał, 2001b), coal mines (Tkocz, 1996, 2006) and the development of individual business entities set up after the new act on economic activity had been introduced (Kamińska, 1994). T. Rachwał (2008), addressing the issues of the functioning of industrial enterprises, presented different approaches to researching enterprises in the field of geography and economics. He drew attention to the changeability of the conditions of changes in the functioning of enterprises and attached the previously mentioned updated questionnaire on the research of an industrial enterprise.

The outlined research problems of an industrial enterprise are complex, and this concerns various issues changing as a result of management processes. It is an extensive base that allows making further attempts to build the theory of conditions and development of industrial enterprises on the basis of geography of industry.

\section{THE CONCEPT OF A HOLISTIC ANALYSIS OF THE CONDITIONS FOR THE FUNCTIONING AND DEVELOPMENT OF AN ENTERPRISE AND INDUSTRIAL ACTIVITY}

In the process of changes in the spatial structure of industry, depending on the attractiveness of spatial systems, the concentration of production and capital potential of manufacturing activity takes place. The production of increasingly complex products and diversified production costs in regional and national systems affect the intensifying processes of internationalisation of production, which affect the intensification of globalisation processes.

Industrial enterprises are not isolated elements, but operate in a specific place and belong to the essential elements of the spatial structure of industry but also to a more complex socio-economic and geographical space. In the process of functioning and 
development, they show passive and active relations with the elements of geographical space (Tab. 1). On the one hand, the operation and development of a company are influenced, to varying degrees, by individual elements of the natural, socio-economic and cultural space, and on the other hand, the enterprise also evokes changes in its surroundings. This results from the location of a new business, emerging new production and service links, capital and finance links, in the scope of management, the use of specific resources for the development of production and the possibility of selling ready products. It is accompanied by the emergence and development of the existing business entities and institutions working for enterprises, but also the disappearance of economic entities that could not adapt to the new situation and the requirements of the emerging market. Enterprises influence their environment as a result of raising the technical level and implementation of new production processes, as well as by offering new products. This has a fundamental impact on the quality of the socio-economic and cultural potential, through the care of the higher quality of the staff, development of educational activities, improvement of the quality of services and public institutions, and others.

In the historical growth process, industrial activity played and continues to play a significant role in increasing the pace and directions of civilisation development. Spatially differentiated economic, social and cultural potential creates specific opportunities to dynamise its growth rate and structural changes, which leads to increasing disproportions in this area. The directions of development and the pace of intensification of production (industrial) activity are determined by the development of basic research, the use of which allows to develop scientific and research progress, and then laboratory work; undertaking experimental production, production on a semi-technical scale, technical and market production. An important role is played by the market, which usually develops or deepens as a result of a larger number of more modern and more economical products being offered.

The processes of geographical space development are the result of the impact of the operation of various economic rules that pursue specific goals. The activity of enterprises is governed by microeconomic regulations, in which the primary emphasis is put on maximising profit (Tab. 2).

The development of regional systems is being influenced by the rules of the mesoeconomics, whose primary goal is to increase the level of socio-economic and cultural development of regional structures. Regional structures are elements of national economy which develop on the basis of macroeconomic rules. On the other hand, specific groups of countries, connected by common economic or political goals (e.g. the European Union) are governed by mega economic rules. Global economy, along with the growing internationalisation of economic activity and the ever-increasing globalisation processes, as well as in the pursuit of limiting the adverse effects of socio-economic inequalities and the elimination of potential threats (incl. ecological and military) in the global space, are shaped according to the rules of global economy.

There are three categories of relationships among the rules of economic development. The first one is the relations taking place in the structure of particular rules of economic development, i.e. in the structure of microeconomic $\left[\mathrm{e}^{\mathrm{e}}{ }_{11}\right]$, mesoeconomic $\left[\mathrm{e}^{\mathrm{e}}{ }_{22}\right]$, macroeconomic $\left[\mathrm{e}_{33}^{\mathrm{e}}\right]$, mega economic $\left[\mathrm{e}^{\mathrm{e}}{ }_{44}\right]$ rules and the rules of the world economics $\left[\mathrm{e}_{55}^{\mathrm{e}}\right]$. The second group presents active relations, which (in rows in the table) determine the impact of a given rule on others, e.g. the impact of microeconomic rules 
Tab. 1. Conditions of the functioning of an industrial enterprise in geographical space

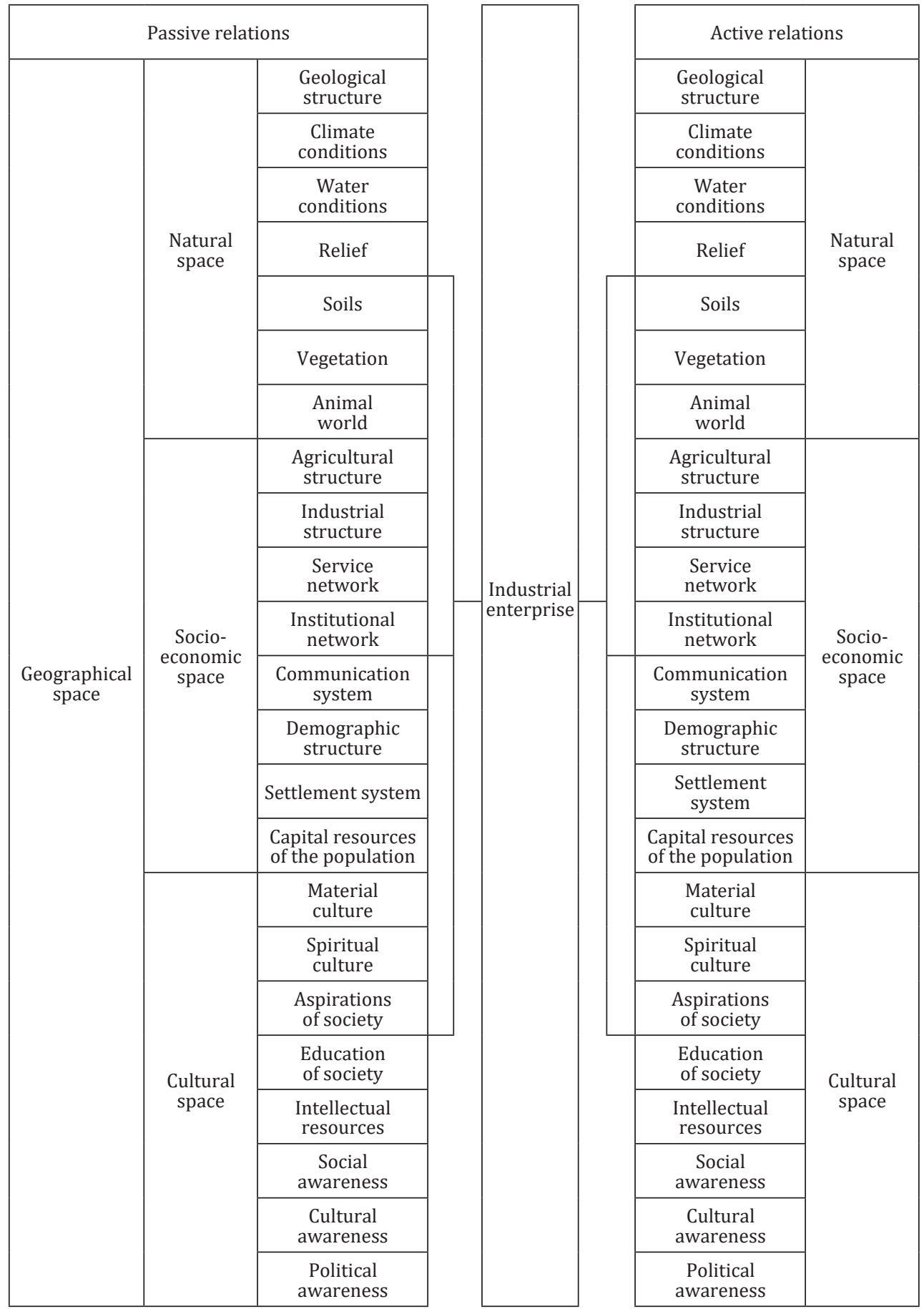

Source: own work 
Tab. 2. Relations between economic rules of economic development

\begin{tabular}{|c|c|c|c|c|c|c|}
\hline \multicolumn{2}{|c|}{ Rules of economic growth } & \multicolumn{5}{|c|}{ Rules of economic development } \\
\hline & & $\mathrm{E}_{1}$ & $\mathrm{E}_{2}$ & $\mathrm{E}_{3}$ & $\mathrm{E}_{4}$ & $\mathrm{E}_{5}$ \\
\hline Microeconomic & $\mathrm{E}_{1}$ & $\mathrm{e}^{\mathrm{e}}{ }_{11}$ & $\mathrm{e}^{\mathrm{e}}{ }_{12}$ & $\mathrm{e}^{\mathrm{e}}{ }_{13}$ & $\mathrm{e}^{\mathrm{e}}{ }_{14}$ & $\mathrm{e}^{\mathrm{e}}{ }_{15}$ \\
\hline Mesoeconomic & $\mathrm{E}_{2}$ & $\mathrm{e}^{\mathrm{e}}{ }_{21}$ & $\mathrm{e}^{\mathrm{e}}{ }_{22}$ & $\mathrm{e}_{23}^{\mathrm{e}}$ & $\mathrm{e}^{\mathrm{e}}{ }_{24}$ & $\mathrm{e}_{25}^{\mathrm{e}}$ \\
\hline Macroeconomic & $\mathrm{E}_{3}$ & $\mathrm{e}^{\mathrm{e}}{ }_{31}$ & $\mathrm{e}^{\mathrm{e}}{ }_{32}$ & $\mathrm{e}^{\mathrm{e}}{ }_{33}$ & $\mathrm{e}^{\mathrm{e}}{ }_{34}$ & $\mathrm{e}_{35}^{\mathrm{e}}$ \\
\hline Mega economy & $\mathrm{E}_{4}$ & $\mathrm{e}_{42}^{\mathrm{e}}$ & $\mathrm{e}_{43}^{\mathrm{e}}$ & $\mathrm{e}_{44}^{\mathrm{e}}$ & $\mathrm{e}_{45}^{\mathrm{e}}$ & $\mathrm{e}_{46}^{\mathrm{e}}$ \\
\hline Global economy & $\mathrm{E}_{5}$ & $\mathrm{e}_{53}^{\mathrm{e}}$ & $\mathrm{e}_{54}^{\mathrm{e}}$ & $\mathrm{e}_{55}^{\mathrm{e}}$ & $\mathrm{e}_{56}^{\mathrm{e}}$ & $\mathrm{e}_{57}^{\mathrm{e}}$ \\
\hline
\end{tabular}

Source: own work

$\left(\mathrm{E}_{1}\right)$ on the mesoeconomic rules is illustrated by the relation $\left[\mathrm{e}^{\mathrm{e}}{ }_{12}\right]$, macroeconomic $\left[\mathrm{e}^{\mathrm{e}}{ }_{13}\right]$, mega economic rules - $\left[\mathrm{e}^{\mathrm{e}}{ }_{14}\right]$ and on the rules of the world economy the relation $\left[\mathrm{e}^{\mathrm{e}}{ }_{15}\right]$. Similarly, macroeconomic rules $\left(\mathrm{E}_{3}\right)$ affect the following rules: microeconomic $\left[\mathrm{e}^{\mathrm{e}}{ }_{31}\right]$, mesoeconomic $\left[\mathrm{e}_{32}^{\mathrm{e}}\right]$, mega economic $\left[\mathrm{e}_{34}^{\mathrm{e}}\right]$, and world economics $\left[\mathrm{e}^{\mathrm{e}}{ }_{35}\right]$. The third category, passive relations, show the influence of individual rules on a given rule (in table columns), e.g. microeconomic rules $\left(\mathrm{E}_{1}\right)$ are influenced by mesoeconomic rules $\left[\mathrm{e}_{21}^{\mathrm{e}}\right.$ ], macroeconomic $\left[\mathrm{e}^{\mathrm{e}}{ }_{31}\right]$, mega economics $\left[\mathrm{e}_{41}^{\mathrm{e}}\right.$ ] and rules of the world economy $\left[\mathrm{e}^{\mathrm{e}}{ }_{51}\right]$. Similarly, the mega economic rules $\left(\mathrm{E}_{4}\right)$ are influenced by microeconomic rules $\left[\mathrm{e}^{\mathrm{e}}{ }_{14}\right]$, mesoeconomic $\left[\mathrm{e}^{\mathrm{e}}{ }_{24}\right]$, macroeconomic $\left[\mathrm{e}^{\mathrm{e}}{ }_{34}\right]$, and world economics $\left[\mathrm{e}^{\mathrm{e}}{ }_{54}\right]$. Similarly, active and passive relations are illustrated by the next tables.

This means that the processes of enterprise growth and activity are the result of overlapping different rules of economic development, which may intensify development processes but may also have some conflicts between them. For example, companies pursuing the principle of profit maximisation seek to limit the size of various benefits (taxes, fees) for regional or national economy, and regional and national economy to achieve their development goals tend to increase them. Similar conflicts are visible in the EU structures. They are connected, among others, with the collection of funds to the common budget by individual member states and then with their division. As a consequence, the relations between the rules of economic development, affect the volatility of conditions that may contribute to the stimulation of production and service activities, but also may pose specific barriers to growth. Therefore, knowledge of these rules is essential for building a business development strategy for various categories of companies and industries, as well as regional and national systems.

Industrial enterprises do not constitute a homogeneous set, but they represent various branches of industry, which show a particular intensity of passive and active connections with specific elements of geographical space. At the same time, depending on the size of the economic potential and the extent of spatial links between production and service and market, they can fulfil the following functions: primary, complementary, 
standard and local (Tab. 3). The primary (leading) functions are characteristic of enterprises with high technical and economic potential and working to meet the needs of the domestic, international or global market. Enterprises working for primary enterprises meet complementary functions. Enterprises with standard functions work mainly for the needs of the regional and supra-regional markets. On the other hand, enterprises with local functions are associated with supralocal and local markets. In the development process, individual categories of enterprises can change their functions in the economic space.

Tab. 3. Relations between functional types of enterprises

\begin{tabular}{|c|c|c|c|c|c|}
\hline \multirow{2}{*}{\multicolumn{2}{|c|}{$\begin{array}{l}\text { Functions of enterprises } \\
\qquad \mathrm{Z}_{1}\end{array}$}} & \multicolumn{4}{|c|}{ Functions of enterprises } \\
\hline & & \multirow{2}{*}{$\frac{\mathrm{Z}_{2}}{\mathrm{z}_{11}}$} & \multirow{2}{*}{$\begin{array}{r}\mathrm{Z}_{3} \\
\mathrm{z}_{12}\end{array}$} & \multirow{2}{*}{$\begin{array}{c}\mathrm{Z}_{4} \\
\mathrm{z}_{13}\end{array}$} & \multirow[b]{2}{*}{$\mathrm{z}_{14}$} \\
\hline Primary & $\mathrm{Z}_{1}$ & & & & \\
\hline Complementary & $\mathrm{Z}_{2}$ & $\mathrm{z}_{21}$ & $\mathrm{z}_{22}$ & $\mathrm{z}_{23}$ & $\mathrm{z}_{24}$ \\
\hline Standard & $\mathrm{Z}_{3}$ & $\mathrm{z}_{31}$ & $\mathrm{z}_{32}$ & $\mathrm{z}_{33}$ & $\mathrm{z}_{34}$ \\
\hline Local & $\mathrm{Z}_{4}$ & $\mathrm{z}_{41}$ & $\mathrm{z}_{42}$ & $\mathrm{z}_{43}$ & $\mathrm{z}_{44}$ \\
\hline
\end{tabular}

Source: own work

The development of enterprises' activities takes place in specific spatial arrangements (local, regional, national). In the process of locating enterprises, or in the search for new places of developing production activity, competitive relations between particular spatial systems intensify (Tab. 4). They occur between the same categories of spatial arrangements (e.g. between local systems) but also between other categories of systems (e.g. between local and regional systems, regional and national, national and European or global). Competitive relations of spatial layouts are manifested mainly in the level of accessibility and infrastructure development, the quality of financial institutions and legal instruments that enable effective production and service activities. Economic, international and spatial policy factors may also contribute to increasing the attractiveness for business development, aimed at, among others, stimulation of socio-economic development of less developed local, regional or individual countries.

An industrial enterprise operates in connection with various spatial environment categories (Tab. 5). They relate to links in the areas of financial, capital and technological flows, machinery equipment, spare parts, repairs, raw materials supply, cooperation supplies, energy and water supply, employment relations, sales of specific product groups, service activities, etc. Relationships between spatial categories of the enterprise and industry environment may change. Therefore, the stability of conditions and the ability to maintain and deepen market links, as well as the possibilities of seeking new relationships that reduce operating costs, are particularly important in this respect. 
Tab. 4. Competitive relations between a given category of spatial systems

\begin{tabular}{|c|c|c|c|c|c|}
\hline \multirow{2}{*}{ Spatial systems } & \multicolumn{5}{|c|}{ Spatial systems } \\
\hline & $\mathrm{U}_{1}$ & $\mathrm{U}_{2}$ & $\mathrm{U}_{3}$ & & $U_{n}$ \\
\hline $\mathrm{U}_{1}$ & $\mathrm{u}_{11}$ & $\mathrm{u}_{12}$ & $\mathrm{u}_{13}$ & & $\mathrm{u}_{1 \mathrm{n}}$ \\
\hline $\mathrm{U}_{2}$ & $\mathrm{u}_{21}$ & $\mathrm{u}_{22}$ & $\mathrm{u}_{23}$ & & $\mathrm{u}_{2 \mathrm{n}}$ \\
\hline $\mathrm{U}_{3}$ & $\mathrm{u}_{31}$ & $\mathrm{u}_{32}$ & $\mathrm{u}_{33}$ & & $\mathrm{u}_{3 \mathrm{n}}$ \\
\hline$\cdot$ & $\cdot$ & $\cdot$ & $\cdot$ & & $\cdot$ \\
\hline $\mathrm{U}_{\mathrm{n}}$ & $\mathrm{u}_{\mathrm{n} 1}$ & $\mathrm{u}_{\mathrm{n} 2}$ & $\mathrm{u}_{\mathrm{n} 3}$ & & $\mathrm{u}_{\mathrm{nn}}$ \\
\hline
\end{tabular}

Source: own work

Tab. 5. Relations between spatial categories of the company's market environment

\begin{tabular}{|c|c|c|c|c|c|c|c|}
\hline \multirow{2}{*}{\multicolumn{2}{|c|}{$\begin{array}{l}\text { Market environment } \\
\qquad \mathrm{P}_{1}\end{array}$}} & Company & Local & Regional & National & European & Global \\
\hline & & & & & & & \\
\hline Company & $\mathrm{P}_{1}$ & $\mathrm{p}_{11}$ & $\mathrm{p}_{12}$ & $\mathrm{p}_{13}$ & $\mathrm{p}_{14}$ & $\mathrm{p}_{15}$ & $\mathrm{p}_{16}$ \\
\hline Local & $\mathrm{P}_{2}$ & $\mathrm{p}_{21}$ & $\mathrm{p}_{22}$ & $\mathrm{p}_{23}$ & $\mathrm{p}_{24}$ & $\mathrm{p}_{25}$ & $\mathrm{p}_{26}$ \\
\hline Regional & $\mathrm{P}_{3}$ & $\mathrm{p}_{31}$ & $\mathrm{p}_{32}$ & $\mathrm{p}_{33}$ & $\mathrm{p}_{34}$ & $\mathrm{p}_{35}$ & $\mathrm{p}_{36}$ \\
\hline National & $\mathrm{P}_{4}$ & $\mathrm{p}_{41}$ & $\mathrm{p}_{42}$ & $\mathrm{p}_{43}$ & $\mathrm{p}_{44}$ & $\mathrm{p}_{45}$ & $\mathrm{p}_{46}$ \\
\hline European & $\mathrm{P}_{5}$ & $\mathrm{p}_{51}$ & $\mathrm{p}_{52}$ & $\mathrm{p}_{53}$ & $\mathrm{p}_{54}$ & $\mathrm{p}_{55}$ & $\mathrm{p}_{56}$ \\
\hline Global & $\mathrm{P}_{6}$ & $\mathrm{p}_{61}$ & $\mathrm{p}_{62}$ & $\mathrm{p}_{63}$ & $\mathrm{p}_{64}$ & $\mathrm{p}_{65}$ & $\mathrm{p}_{66}$ \\
\hline
\end{tabular}

Source: own work

An essential role in stimulating the business activity of enterprises and socio-economic and cultural development of enterprise systems is played by the quality and competence of elites that represent governmental, non-governmental and self-governmental administration, as well as representatives of political parties in power and in opposition. They can manage various categories of spatial arrangements, from the global and EU system, through national and regional systems to local systems. The functioning of the authorities may be a consequence of democratic rules of choice, of forceful taking over, or of imposing power by the interference of external factors. The elites of 
power within a given spatial layout and representing different categories of systems may maintain positive, neutral or negative relations between each other (Tab. 6). The quality of the elites managing individual spatial systems is primarily influenced by intellectual resources, education level, personal aspirations and the will to develop the socio-economic and cultural management of the area while respecting ecological conditions. During the period of exercising power, they may create favourable conditions for the development of enterprises, stimulate the emergence of new business entities, affect the acceleration of processes of generating internal development factors and increase attractiveness for attracting favourable factors from the environment, but may also contribute to the weakening of growth and even recession.

Tab. 6. Relations between power elites

\begin{tabular}{|c|c|c|c|c|c|c|}
\hline \multirow{2}{*}{\multicolumn{2}{|c|}{$\begin{array}{c}\text { Power elites } \\
\mathrm{W}_{1}\end{array}$}} & Global & UE & National & Regional & Local \\
\hline & & W & W & W & W & \\
\hline Global & $\mathrm{W}_{1}$ & $\mathrm{w}^{\mathrm{w}}{ }_{11}$ & $\mathrm{w}^{\mathrm{w}}{ }_{12}$ & $\mathrm{w}^{\mathrm{w}}{ }_{13}$ & $\mathrm{w}^{\mathrm{w}}{ }_{14}$ & $\mathrm{~W}^{\mathrm{w}}{ }_{15}$ \\
\hline UE & $\mathrm{W}_{2}$ & $\mathrm{w}^{\mathrm{w}}{ }_{21}$ & $\mathrm{w}^{\mathrm{w}}{ }_{22}$ & $\mathrm{w}^{\mathrm{w}}{ }_{23}$ & $\mathrm{w}^{\mathrm{w}}{ }_{24}$ & $\mathrm{w}^{\mathrm{w}}{ }_{25}$ \\
\hline National & $\mathrm{W}_{3}$ & $\mathrm{w}^{\mathrm{w}}{ }_{31}$ & $\mathrm{w}^{\mathrm{w}}{ }_{32}$ & $\mathrm{w}^{\mathrm{w}}{ }_{33}$ & $\mathrm{w}^{\mathrm{w}}{ }_{34}$ & $\mathrm{w}^{\mathrm{w}}{ }_{35}$ \\
\hline Regional & $\mathrm{W}_{4}$ & $\mathrm{~W}_{41}^{\mathrm{w}}$ & $\mathrm{w}^{\mathrm{w}}{ }_{42}$ & $\mathrm{w}^{\mathrm{w}}{ }_{43}$ & $\mathrm{w}^{\mathrm{w}}{ }_{44}$ & $\mathrm{~W}^{\mathrm{w}}{ }_{45}$ \\
\hline Local & $\mathrm{W}_{5}$ & $\mathrm{w}^{\mathrm{w}}{ }_{51}$ & $\mathrm{w}^{\mathrm{w}}{ }_{52}$ & $\mathrm{w}^{\mathrm{w}}{ }_{53}$ & $\mathrm{w}_{54}^{\mathrm{w}}$ & $\mathrm{w}^{\mathrm{w}}{ }_{55}$ \\
\hline
\end{tabular}

Source: own work

The industrial, economic, social, regional, European and global policies influence the process of enterprise development and the activity of industry. There are specific relations between particular policy types, which as a result of competition rules lead to an increase in the business activity of enterprises and individual industries, but also their stagnation, collapse or disappearance (Tab. 7). To a large extent, it depends on the degree of modernity of the offered products, the intensification of the quality of cooperative relations and changing market needs. In general, negotiations between politicians should aim at increasing the efficiency of production or service activities by developing investment activities, implementing modern production and management methods, socio-economic and cultural development, and raising the level and quality of life. As a result of the lack of coordinated goals and actions taken, particular types of policy may facilitate but also hinder access to mineral resources, capital and financial resources and the market.

The presented considerations indicate a very complex mechanism of functioning and development opportunities of an industrial enterprise and industry in the structure of the environment (Tab. 8). Three categories of relationships deserve particular attention in the management process. 
Tab. 7. Relations between policy types

\begin{tabular}{|c|c|c|c|c|c|c|c|c|}
\hline \multicolumn{2}{|c|}{\begin{tabular}{c} 
Policy \\
\multicolumn{2}{|c|}{$\mathrm{D}_{1}$}
\end{tabular}} & Enterprise & Industrial & Economic & Social & Regional & European & Global \\
\cline { 2 - 9 } Enterprise & $\mathrm{D}_{1}$ & $\mathrm{~d}_{11}$ & $\mathrm{D}_{3}$ & $\mathrm{D}_{4}$ & $\mathrm{D}_{5}$ & $\mathrm{D}_{6}$ & $\mathrm{D}_{7}$ & \\
\hline Industrial & $\mathrm{D}_{2}$ & $\mathrm{~d}_{21}$ & $\mathrm{~d}_{22}$ & $\mathrm{~d}_{23}$ & $\mathrm{~d}_{24}$ & $\mathrm{~d}_{25}$ & $\mathrm{~d}_{26}$ & $\mathrm{~d}_{14}$ \\
\hline Economic & $\mathrm{D}_{3}$ & $\mathrm{~d}_{31}$ & $\mathrm{~d}_{32}$ & $\mathrm{~d}_{33}$ & $\mathrm{~d}_{34}$ & $\mathrm{~d}_{35}$ & $\mathrm{~d}_{36}$ & $\mathrm{~d}_{37}$ \\
\hline Social & $\mathrm{D}_{4}$ & $\mathrm{~d}_{41}$ & $\mathrm{~d}_{42}$ & $\mathrm{~d}_{43}$ & $\mathrm{~d}_{44}$ & $\mathrm{~d}_{45}$ & $\mathrm{~d}_{46}$ & $\mathrm{~d}_{47}$ \\
\hline Regional & $\mathrm{D}_{5}$ & $\mathrm{~d}_{51}$ & $\mathrm{~d}_{52}$ & $\mathrm{~d}_{53}$ & $\mathrm{~d}_{54}$ & $\mathrm{~d}_{55}$ & $\mathrm{~d}_{56}$ & $\mathrm{~d}_{57}$ \\
\hline European & $\mathrm{D}_{6}$ & $\mathrm{~d}_{61}$ & $\mathrm{~d}_{62}$ & $\mathrm{~d}_{63}$ & $\mathrm{~d}_{64}$ & $\mathrm{~d}_{65}$ & $\mathrm{~d}_{66}$ & $\mathrm{~d}_{67}$ \\
\hline Global & $\mathrm{D}_{7}$ & $\mathrm{~d}_{71}$ & $\mathrm{~d}_{72}$ & $\mathrm{~d}_{73}$ & $\mathrm{~d}_{74}$ & $\mathrm{~d}_{75}$ & $\mathrm{~d}_{76}$ & $\mathrm{~d}_{77}$ \\
\hline
\end{tabular}

Source: own work

Tab. 8. Conditions of the functioning of industrial enterprises

\begin{tabular}{|c|c|c|c|c|c|c|c|c|}
\hline \multirow{2}{*}{\multicolumn{2}{|c|}{$\begin{array}{c}\text { Types of } \\
\text { conditions } \\
X_{j}\end{array}$}} & Enterprise & $\begin{array}{c}\text { Functional } \\
\text { types of } \\
\text { enterprises }\end{array}$ & $\begin{array}{c}\text { Elements of } \\
\text { geographical } \\
\text { space }\end{array}$ & $\begin{array}{c}\text { Rules of } \\
\text { economic } \\
\text { development }\end{array}$ & $\begin{array}{c}\text { Scales of } \\
\text { spatial } \\
\text { systems }\end{array}$ & $\begin{array}{c}\text { Power } \\
\text { elites }\end{array}$ & $\begin{array}{c}\text { Types } \\
\text { of } \\
\text { policies }\end{array}$ \\
\hline & & $\mathrm{Z}_{\mathrm{j}}$ & $G_{j}$ & $E_{j}$ & $P_{j}$ & $W_{j}$ & $D_{j}$ & \\
\hline Enterprise & $\mathrm{X}_{\mathrm{i}}$ & $\mathrm{x}_{\mathrm{ij}}^{\mathrm{x}}$ & $\mathrm{X}_{\mathrm{ij}}^{\mathrm{z}}$ & $X_{i j}^{g}$ & $\mathrm{x}_{\mathrm{ij}}^{\mathrm{e}}$ & $\mathrm{x}_{\mathrm{ij}}^{\mathrm{p}}$ & $\mathrm{x}^{\mathrm{w}}{ }_{\mathrm{ij}}$ & $\mathrm{X}^{\mathrm{d}}{ }_{\mathrm{ij}}$ \\
\hline $\begin{array}{l}\text { Functional } \\
\text { types of } \\
\text { enterprises }\end{array}$ & $\mathrm{Z}_{\mathrm{i}}$ & $\mathrm{Z}^{\mathrm{x}} \mathrm{ij}$ & $\mathrm{Z}_{\mathrm{ij}}^{\mathrm{z}}$ & $\mathrm{Z}_{\mathrm{ij}}^{\mathrm{d}}$ & $\mathrm{Z}^{\mathrm{e}} \mathrm{ij}_{\mathrm{ij}}$ & $\mathrm{Z}^{\mathrm{p}}{ }_{\mathrm{ij}}$ & $\mathrm{Z}^{\mathrm{w}}{ }_{\mathrm{ij}}$ & $\mathrm{Z}^{\mathrm{d}}{ }_{\mathrm{ij}}$ \\
\hline $\begin{array}{l}\text { Elements of } \\
\text { geographical } \\
\text { space }\end{array}$ & $\mathrm{G}_{\mathrm{i}}$ & $\mathrm{g}^{\mathrm{x}} \mathrm{ij}^{\mathrm{x}}$ & $\mathrm{g}_{\mathrm{ij}}^{\mathrm{z}}$ & $\mathrm{g}_{\mathrm{ij}}^{\mathrm{g}}$ & $\mathrm{g}_{\mathrm{ij}}^{\mathrm{e}}$ & $g^{p}{ }_{i j}$ & $\mathrm{~g}^{\mathrm{w}}{ }_{\mathrm{ij}}$ & $g^{d}{ }_{i j}$ \\
\hline $\begin{array}{c}\text { Rules of } \\
\text { economic } \\
\text { development }\end{array}$ & $\mathrm{E}_{\mathrm{i}}$ & $\mathrm{e}^{\mathrm{x}}{ }_{\mathrm{ij}}$ & $\mathrm{e}^{\mathrm{z}}{ }_{\mathrm{ij}}$ & $\mathrm{e}^{\mathrm{g}} \mathrm{ij}$ & $\mathrm{e}^{\mathrm{e}_{\mathrm{ij}}}$ & $\mathrm{e}^{\mathrm{p}}{ }_{\mathrm{ij}}$ & $\mathrm{e}^{\mathrm{w}}{ }_{\mathrm{ij}}$ & $e^{d i j}$ \\
\hline $\begin{array}{c}\text { Scales of } \\
\text { spatial } \\
\text { systems }\end{array}$ & $P_{i}$ & $\mathrm{p}^{\mathrm{x}} \mathrm{ij}^{\mathrm{x}}$ & $\mathrm{p}_{\mathrm{ij}}^{\mathrm{z}}$ & $\mathrm{p}^{\mathrm{g}} \mathrm{ij}_{\mathrm{ij}}$ & $\mathrm{p}^{\mathrm{p}}{ }_{\mathrm{ij}}$ & $\mathrm{p}^{\mathrm{p}} \mathrm{ij}_{\mathrm{j}}$ & $\mathrm{p}^{\mathrm{w}}{ }_{\mathrm{ij}}$ & $\mathrm{p}^{\mathrm{d}}{ }_{\mathrm{ij}}$ \\
\hline Power elites & $\mathrm{W}_{\mathrm{i}}$ & $\mathrm{w}^{\mathrm{x}}{ }_{\mathrm{ij}}$ & $\mathrm{w}_{\mathrm{ij}}^{\mathrm{z}}$ & $w^{w}{ }_{i j}$ & $\mathrm{w}_{\mathrm{ij}}^{\mathrm{e}}$ & $\mathrm{w}^{\mathrm{p}}{ }_{\mathrm{ij}}$ & $\mathrm{w}^{\mathrm{w}}{ }_{\mathrm{ij}}$ & $\mathrm{w}^{\mathrm{d}}{ }_{\mathrm{ij}}$ \\
\hline $\begin{array}{l}\text { Types of } \\
\text { policies }\end{array}$ & $\mathrm{D}_{\mathrm{i}}$ & $d^{x}{ }_{i j}$ & $\mathrm{~d}^{\mathrm{z}}{ }_{\mathrm{ij}}$ & $\mathrm{d}_{\mathrm{ij}}^{\mathrm{g}}$ & $\mathrm{d}^{\mathrm{e}}{ }_{\mathrm{ij}}$ & $\mathrm{d}^{\mathrm{p}}{ }_{\mathrm{ij}}$ & $\mathrm{d}^{\mathrm{w}}{ }_{\mathrm{ij}}$ & $d^{d i j}$ \\
\hline
\end{tabular}

Source: own work 
The first category presents internal relations taking place in the structure of particular conditions, e.g. the relations taking place in the enterprise structure $-\left[\mathrm{x}_{\mathrm{ij}}^{\mathrm{x}}\right]$, relationships between economic development rules $-\left[\mathrm{e}_{\mathrm{ij}}^{\mathrm{e}}\right]$, relations between power elites $-\left[\mathrm{w}^{\mathrm{w}}{ }_{\mathrm{ij}}\right]$ and relations between different categories of policies $-\left[\mathrm{d}_{\mathrm{ij}}^{\mathrm{d}}\right]$.

Active relations are illustrated in the rows of the table, which present, for example, the influence of the company on the elements of geographical space $-\left[\mathrm{x}_{\mathrm{ij}}^{\mathrm{g}}\right]$, on the power elites $-\left[\mathrm{x}^{\mathrm{w}}{ }_{\mathrm{ij}}\right]$ and the types of policies $-\left[\mathrm{x}_{\mathrm{ij}}^{\mathrm{d}}\right]$. Similarly, the influence of the power elites on the enterprise is represented by the relation $\left[\mathrm{w}_{\mathrm{ij}}^{\mathrm{x}}\right]$ and on the elements of geographical space $-\left[\mathrm{w}^{\mathrm{d}}{ }_{\mathrm{ij}}\right]$.

Passive relations show, for example, impacts on the enterprise by the elements of geographical space $-\left[\mathrm{z}_{\mathrm{ij}}^{\mathrm{x}}\right]$, the influence of economic development rules $-\left[\mathrm{e}^{\mathrm{x}}{ }_{\mathrm{ij}}\right]$, of power elites $-\left[\mathrm{w}^{\mathrm{x}}{ }_{\mathrm{ij}}\right]$ and types of policies $-\left[\mathrm{d}_{\mathrm{ij}}^{\mathrm{x}}\right]$. Similarly, the elements of geographical space are influenced by the rules of economic development $-\left[\mathrm{e}_{\mathrm{ij}}^{\mathrm{g}}\right]$, power elites $-\left[\mathrm{w}_{\mathrm{ij}}^{\mathrm{d}}\right]$, and types of policies $-\left[\mathrm{d}_{\mathrm{ij}}^{\mathrm{g}}\right]$.

The potential and quality of development determinants of elements of geographical space and the relations that occur between them often create different opportunities for developing the activities of industrial enterprises. Favourable conditions in specific spatial systems lead to a spatial concentration of industrial enterprises and economic potential in their area, while unfavourable conditions deprive enterprises of the possibility of locating and operating enterprises. The consequence of this is the intensifying spatial polarisation processes manifesting themselves in the progressive diversification of the level of economic, social and cultural development of spatial systems that lead to the differentiation of the level and quality of life of the population.

An essential factor in the development of enterprises' operations is also the progressive process of concentration of capital occurring both in organisational structures and spatial systems. This process takes place both as a result of an increase in investment activity and an increase of the potential of a given enterprise, as well as through various types of mergers and acquisitions of similar companies or functionally related business entities. These processes affect the emergence of increasingly organised enterprises, which are currently represented by global industrial, service, capital, financial and the like corporations. They are based on efforts to monopolise economic activity, limit competition of other companies, strengthen their position on the market and, as a consequence, increase efficiency as a result of limiting the costs of production or service activities.

The outlined concept enables a comprehensive analysis of the functioning and development of an industrial enterprise and industry in geographical space. It is the basis for further studies related to the operation and development of various enterprises, as well as multiple branches of industry. It underlines the necessity of continuous and more and more precise studying of the complexity of the processes of functioning and transformation of enterprises, individual branches and the entire industry sector, in various spatial environment categories, as well as the impact of economic rules, quality of elites and implemented policies on their development. It should be assumed that as a result of scientific, research, technological and technical progress, there are better and better products that intensify the development of civilisation. It is accompanied by an intensifying process of concentration of management and capital, as well as the possibilities of deepening existing and acquiring new markets, shaping new or intensifying existing functional connections occurring in the structure of developing global 
corporations, as well as between individual industrial enterprises and economic sectors.

The general wording is of great importance for application activities in the area of building and improving development strategies of enterprises, industry departments, as well as regional, national or European systems. The identification of functional connections between the company and its surroundings remains a particularly pressing problem, together with the issues to what extent the developing industry is a stable element of spatial structures and to what extent its potential may affect changes in the economic, social and cultural development of local, regional, national, European or world systems.

\section{References}

Adamczyk, Z. (1994). Funkcjonowanie przemysłu mięsnego w nowych warunkach społeczno-ekonomicznych gospodarowania (na przykładzie Zakładów Mięsnych w Krotoszynie) [The functioning of the meat industry in the new socio-economic management conditions (on the example of Meat Processing Plant in Krotoszyn)]. In: Funkcjonowanie przedsiębiorstw przemysłowych $w$ zmieniających się warunkach gospodarowania [Functioning of industrial enterprises in the changing management conditions]. Warszawa-Kraków: Centralny Ośrodek Metodyczny Studiów Nauczycielskich, Komisja Geografii Przemysłu Polskiego Towarzystwa Geograficznego, Wydawnictwo Naukowe Wyższej Szkoły Pedagogicznej w Krakowie.

Dobrowolska, M. (1965). Tendencje rozwojowe geografii przemysłu w okresie XX lecia Polski Ludowej [Trends in the development of the geography of industry during the twenty years of the People's Republic of Poland]. Przeglad Geograficzny, 4.

Domański, R. (1965). O teoretyczną geografię przemysłu [For the theoretical geography of industry]. Przegląd Geograficzny, 37(2).

Domański, B. (1997). Geografia przedsiębiorstw - niedoceniany nurt badań w polskiej geografii ekonomicznej [Geography of enterprises - an undervalued research trend in the Polish economic geography]. In: B. Domański (ed.). Geografia, Człowiek, Gospodarka [Geography, Man, Economy]. Kraków: Wydawnictwo Instytutu Geografii Uniwersytetu Jagiellońskiego, 101-112.

Domański, R. (2018). Gospodarka przestrzenna. Koncepcje teoretyczne [Spatial management. Theoretical concepts]. Poznań: Wydawnictwo Uniwersytetu Ekonomicznego w Krakowie.

Dziadek, S. (1988). Lokalizacja zakładu przemysłowego a ochrona środowiska przyrodniczego[Location of an industrial plant vs environmental protection]. Materiały $i$ sprawozdania Centralnego Ośrodka Metodycznego Kształcenia Nauczycieli, 16.

Dziewoński, K. (1949). Zagadnienie zespołu produkcyjnego w teorii lokalizacji i praktyce planowania [The issue of the production complex in the theory of location and planning practice]. Ekonomista, 3, 108-123.

Fierla, I. (1958). Zakład przemysłowy jako przedmiot badań geograficzno-ekonomicznych [Industrial plant as a subject of geographic and economic research]. Zeszyty Naukowe Szkoły Głównej Planowania i Statystyki, 7.

Fierla, I. (1962). Zakład przemysłowy jako przedmiot badań geograficzno-ekonomicznych [Industrial plant as a subject of geographic and economic research]. Zeszyty Naukowe Szkoły Głównej Planowania i Statystyki, 41.

Fierla, I. (1987). Lokalizacja przemysłu [Location of industry]. Warszawa: Polskie Wwydawnictwo Ekonomiczne.

Fierla, I. (1988). Problemy lokalizacji zakładów przemysłowych [Problems of locating industrial plants]. In: Z. Zioło (ed.). Zakład przemysłowy w akademickim kształceniu nauczycieli geografii [Industrial plant in the academic education of geography teachers]. Kraków: Wydawnictwo Naukowe Wyższej Szkoły Pedagogicznej, 25-45.

Fierla, I. (1994a). Zmiany uwarunkowań lokalizacji przemysłu w Polsce, cz. I [Changes of conditions of the location of the industry in Poland, part I]. Warszawa: Szkoła Główna Handlowa. 
Fierla, I. (1994b). Zmiany uwarunkowań lokalizacji przemysłu w Polsce, cz. II [Changes of conditions of the location of the industry in Poland, part II]. Warszawa: Szkoła Główna Handlowa.

Florence, P.S. (1965). Brytyjski i amerykański system przemysłowy [British and American industrial system]. Warszawa: Wydawnictwo Naukowe PWN.

Jażewicz, I., Rydz, E. (1994). Zmiany w funkcjonowaniu zakładów przemysłu spożywczego Słupska w latach 1985-1992 [Changes in the functioning of food industry plants in Słupsk in 1985-1992]. In: Funkcjonowanie przedsiębiorstw przemysłowych $w$ zmieniających się warunkach gospodarowania [Functioning of industrial enterprises in the changing economic conditions]. Warszawa-Kraków: Centralny Ośrodek Metodyczny Studiów Nauczycielskich, Komisja Geografii Przemysłu Polskiego Towarzystwa Geograficznego, Wydawnictwo Naukowe Wyższej Szkoły Pedagogicznej w Krakowie.

Kamińska, V. (1994). Rozwój indywidualnych podmiotów gospodarczych w województwie kieleckim [Development of individual business entities in the Kielce voivodeship]. In: Funkcjonowanie przedsiębiorstw przemysłowych $w$ zmieniajacych się warunkach gospodarowania [Functioning of industrial enterprises in the changing economic conditions]. Warszawa-Kraków: Centralny Ośrodek Metodyczny Studiów Nauczycielskich, Komisja Geografii Przemysłu Polskiego Towarzystwa Geograficznego, Wydawnictwo Naukowe Wyższej Szkoły Pedagogicznej w Krakowie.

Kozysa, J., Miszczuk, A., Żuk, K. (1994). Procesy prywatyzacji przedsiębiorstw przemysłowych Lubelszczyzny [Privatisation processes of industrial enterprises in the Lublin region]. Warszawa-Kraków: Centralny Ośrodek Metodyczny Studiów Nauczycielskich, Komisja Geografii Przemysłu Polskiego Towarzystwa Geograficznego, Wydawnictwo Naukowe Wyższej Szkoły Pedagogicznej w Krakowie.

Kuciński, K. (1994). Przestrzenne aspekty business planu [Spatial aspects of the business plan]. In: Funkcjonowanie przedsiębiorstw przemysłowych $w$ zmieniajacych się warunkach gospodarowania [Functioning of industrial enterprises in the changing economic conditions]. Warszawa-Kraków: Centralny Ośrodek Metodyczny Studiów Nauczycielskich, Komisja Geografii Przemysłu Polskiego Towarzystwa Geograficznego, Wydawnictwo Naukowe Wyższej Szkoły Pedagogicznej w Krakowie.

Kuciński, K. (2006). Polskie przedsiębiorstwa wobec globalnej konkurencji [Polish enterprises in relation to global competition]. Warszawa: Szkoła Główna Handlowa, Instytut Funkcjonowania gospodarki Narodowej.

Kuciński, K. (2009). Strategie przedsiębiorstw wobec wymogów zrównoważonego rozwoju [Business strategies towards sustainable development requirements]. Warszawa: Oficyna Wydawnicza Szkoły Głównej Handlowej.

Kukliński, A. (1954). Zakład przemysłowy w uniwersyteckim nauczaniu geografii [The industrial plant in the university teaching of geography]. Czasopismo Geograficzne, 4.

Kukliński, A. (1959). Struktura przestrzenna przemysłu cegielnianego na Ziemiach Zachodnich w epoce kapitalizmu [Spatial structure of the brick industry in the Western Lands in the era of capitalism]. Prace Geograficzne Instytutu Geografii Polskiej Akademii Nauk, 18.

Makieła, Z. (1988). Powiązania zakładu przemysłowego z elementami infrastruktury technicznej [Associations of an industrial plant with elements of technical infrastructure]. Materiaty i Sprawozdania Centralnego Ośrodka Metodycznego Kształcenia Nauczycieli, 16.

Matykowski, R., Szulc, R. (1994). Przekształcenia własnościowe przedsiębiorstw państwowych w województwie poznańskim [Ownership transformation of state enterprises in the Poznań voivodeship]. Funkcjonowanie przedsiębiorstw przemysłowych w zmieniających się warunkach gospodarowania [Functioning of industrial enterprises in the changing economic conditions]. Warszawa-Kraków: Centralny Ośrodek Metodyczny Studiów Nauczycielskich, Komisja Geografii Przemysłu Polskiego Towarzystwa Geograficznego, Wydawnictwo Naukowe Wyższej Szkoły Pedagogicznej w Krakowie.

Niżnik, A.M., Rilej, R.C. (1994). Możliwości wykorzystania doświadczeń gospodarki kapitalistycznej w tworzeniu nowego polskiego ładu gospodarczego (przykład dwóch ośrodków przemysłu włókienniczego) [Possibilities of using the experience of the capitalist economy in creating a new Polish economic order (example of two centers of textile industry)]. In: Funkcjonowanie przedsiębiorstw przemysłowych $w$ zmieniajacych się warunkach gospodarowania [Functioning of industrial enterprises in the changing economic conditions]. 
Warszawa-Kraków: Centralny Ośrodek Metodyczny Studiów Nauczycielskich, Komisja Geografii Przemysłu Polskiego Towarzystwa Geograficznego, Wydawnictwo Naukowe Wyższej Szkoły Pedagogicznej w Krakowie.

Ohme, J. (1988). Problemy siły roboczej w zakładzie przemysłowym [w] Zakład przemysłowy $w$ akademickim kształceniu nauczycieli geografii [Problems of workforce in an industrial plant [in] An industrial plant in the academic education of geography teachers]. WarszawaKraków: Centralny Ośrodek Metodyczny Studiów Nauczycielskich, Komisja Geografii Przemysłu Polskiego Towarzystwa Geograficznego, Wydawnictwo Naukowe Wyższej Szkoły Pedagogicznej w Krakowie.

Ormicki, W. (1934). Zakład przemysłowy przedmiotem badań geograficznych. [The industrial plant as a subject to geographical research.], Wiadomości geograficzne, No 1-4.

Pakuła, L. (1960). Kształtowanie się ośrodków przemysłowych powiatu chrzanowskiego [Formation of industrial centers of the Chrzanów poviat]. Czasopismo Geograficzne, 4.

Pakuła, L. (1965). Kształtowanie się i struktura Zachodnio-Krakowskiego Kompleksu Przemysłowego, [Formation and structure of the West-Kraków Industrial Complex]. Biuletyn Komitetu Przestrzennego Zagospodarowania Kraju Polskiej Akademii Nauk, 2.

Pakuła, L. (1967). Uwagi o prowadzeniu ćwiczeń terenowych z geografii Przemysłu [Remarks on conducting field exercises in the geography of industry]. Prace z dydaktyki szkoły wyższej [Studies in the HE didactics], 4.

Parysek, J. (1994). Zachowania przestrzenne przedsiębiorstw przemysłowych w nowych warunkach społeczno-ustrojowych (na przykładzie Swarzęckich Fabryk Mebli SA) [Spatial behaviours of industrial enterprises in the new socio-political conditions (on the example of Swarzęc Furniture Factory SA)]. In: Funkcjonowanie przedsiębiorstw przemysłowych w zmieniajacych się warunkach gospodarowania [Functioning of industrial enterprises in th changing economic conditions]. Warszawa-Kraków: Centralny Ośrodek Metodyczny Studiów Nauczycielskich, Komisja Geografii Przemysłu Polskiego Towarzystwa Geograficznego, Wydawnictwo Naukowe Wyższej Szkoły Pedagogicznej w Krakowie.

Pączka, S. (1994). Badania dotyczące funkcjonowania przedsiębiorstw przemysłowych w zmieniających się warunkach gospodarowania w Polsce [Research on the functioning of industrial enterprises in the changing management conditions in Poland]. In: Funkcjonowanie przedsiębiorstw przemysłowych $w$ zmieniających się warunkach gospodarowania [Functioning of industrial enterprises in the changing economic conditions]. Warszawa-Kraków: Centralny Ośrodek Metodyczny Studiów Nauczycielskich, Komisja Geografii Przemysłu Polskiego Towarzystwa Geograficznego, Wydawnictwo Naukowe Wyższej Szkoły Pedagogicznej w Krakowie.

Piskorz, S. (1988). Tematyka zakładu przemysłowego w nauczaniu geografii w szkole podstawowej i średniej [Theme of the industrial plant in teaching geography in primary and secondary school]. Zakład przemysłowy w akademickim kształceniu nauczycieli geografii [Industrial plant in the academic education of geography teachers]. Warszawa-Kraków: Centralny Ośrodek Metodyczny Studiów Nauczycielskich, Komisja Geografii Przemysłu Polskiego Towarzystwa Geograficznego, Wydawnictwo Naukowe Wyższej Szkoły Pedagogicznej w Krakowie.

Rachwał, T. (2001a). Proces restrukturyzacji Zakładów Mięsnych „Nisko” S.A. jako potencjalny czynnik aktywizacji rolniczej bazy surowcowej północnej części województwa podkarpackiego [The restructuring process of Meat Processing Plant "Nisko" S.A. as a potential factor for the activation of the agricultural raw material base in the northern part of Podkarpackie Voivodeship]. Prace Komisji Geografii Przemysłu Polskiego Towarzystwa Geograficznego [Studies of the Industrial Geography Commission of the Polish Geographical Society], 3, 181189.

Rachwał, T. (2001b). Funkcjonowanie Krakowskich Zakładów Elektronicznych „TELPOD” w świetle przemian w polskim przemyśle elektronicznym [Operation of the Kraków Electronic Plants "TELPOD" in the light of changes in the Polish electronic industry]. Prace Komisji Geografii Przemysłu Polskiego Towarzystwa Geograficznego [Studies of the Industrial Geography Commission of the Polish Geographical Society], 3, 167-180.

Rachwał, T. (2003). Globalne uwarunkowania restrukturyzacji przedsiębiorstw przemysłowych Polski Południowo-Wschodniej [The effects of restructuring of selected industrial enter- 
prises in South-Eastern Poland]. Prace Komisji Geografii Przemysłu Polskiego Towarzystwa Geograficznego [Studies of the Industrial Geography Commission of the Polish Geographical Society], 6, 129-138.

Rachwał, T. (2006). Efekty restrukturyzacji wybranych przedsiębiorstw przemysłowych Polski Południowo-Wschodniej [Effects of restructurings of industrial enterprises in south-east Poland]. Prace Komisji Geografii Przemysłu Polskiego Towarzystwa Geograficznego [Studies of the Industrial Geography Commission of the Polish Geographical Society], 9, 98-115.

Rachwał, T. (2008). Problematyka badawcza funkcjonowania przedsiębiorstw przemysłowych [Research problems concerning the functioning of industrial enterprises]. Prace Komisji Geografii Przemysłu Polskiego Towarzystwa Geograficznego [Studies of the Industrial Geography Commission of the Polish Geographical Society], 11, 53-85.

Rochnowski, H. (1994). Przekształcenia funkcjonalne Spółki Toruń-Pacific Company LTD [Functional transformations of the Torun-Pacific Company LTD]. In: Funkcjonowanie przedsiębiorstw przemysłowych $w$ zmieniających się warunkach gospodarowania [Functioning of industrial enterprises in the changing economic conditions]. Warszawa-Kraków: Centralny Ośrodek Metodyczny Studiów Nauczycielskich, Komisja Geografii Przemysłu Polskiego Towarzystwa Geograficznego, Wydawnictwo Naukowe Wyższej Szkoły Pedagogicznej w Krakowie.

Secomski, K. (1956). Wstęp do teorii rozmieszczenia sił wytwórczych [Introduction to the theory of the distribution of productive forces]. Warszawa: PWG.

Soja, M. (1988). Problemy zatrudnienie w zakładzie przemysłowym [Problems of employment in an industrial plant]. In: Zakład przemysłowy w akademickim kształceniu nauczycieli geografii [An industrial plant in the academic education of geography teachers]. WarszawaKraków: Centralny Ośrodek Metodyczny Studiów Nauczycielskich, Komisja Geografii Przemysłu Polskiego Towarzystwa Geograficznego, Wydawnictwo Naukowe Wyższej Szkoły Pedagogicznej w Krakowie.

Stiepanow, P. (1955). Metodyka badań przedsiębiorstwa przemysłowego i przemysłu regionu [Research methodology of industrial enterprise and industry of the region]. Przeglaqd Zagranicznej Literatury Geograficznej, 3.

Stryjakiewicz, T. (1994). Problematyka przedsiębiorstwa w pracach Komisji Przemian Przemysłu i Komisji Organizacji Przestrzeni Przemysłowej Międzynarodowej Unii Geograficznej [Enterprise as the theme in the studies of the Commission of the Dynamics of Industry and the Commission of the Industrial Space Organisation of the International Geographical Union]. In: Funkcjonowanie przedsiębiorstw przemysłowych $w$ zmieniajacych się warunkach gospodarowania [Functioning of industrial enterprises in the changing economic conditions]. Warszawa-Kraków: Centralny Ośrodek Metodyczny Studiów Nauczycielskich, Komisja Geografii Przemysłu Polskiego Towarzystwa Geograficznego, Wydawnictwo Naukowe Wyższej Szkoły Pedagogicznej w Krakowie.

Tkocz, M. (1996). Funkcjonowanie kopalń węgla kamiennego w warunkach kształtowania się gospodarki rynkowej [Functioning of coal mines in the conditions of market economy development]. In: Z. Zioło (ed.). Wpływ procesów transformacji gospodarki narodowej na funkcjonowanie jednostek gospodarczych i układów przestrzennych [Impact of transformation processes of the national economy on the functioning of economic units and spatial systems]. Warszawa-Kraków: Komisja Geografii Przemysłu Polskiego Towarzystwa Geograficznego, Instytut Geografii Wyższej Szkoły Pedagogicznej w Krakowie, 60-68.

Tkocz, M. (2006). Efekty restrukturyzacji górnictwa węgla kamiennego w Polsce [Effects of hard coal mining restructuring in Poland]. Prace Komisji Geografii Przemysłu Polskiego Towarzystwa Geograficznego [Studies of the Industrial Geography Commission of the Polish Geographical Society], 9, 28-39.

Tobolska, A. (1994). Funkcjonowanie „Amino” SA w zmieniających się warunkach ekonomicznych i społecznych [Operation of the company „Amino" SA in the changing economic and social conditions]. In: Funkcjonowanie przedsiębiorstw przemysłowych $w$ zmieniających się warunkach gospodarowania [Functioning of industrial enterprises in the changing economic conditions]. Warszawa-Kraków: Centralny Ośrodek Metodyczny Studiów Nauczycielskich, Komisja Geografii Przemysłu Polskiego Towarzystwa Geograficznego, Wydawnictwo Naukowe Wyższej Szkoły Pedagogicznej w Krakowie. 
Troc, M. (1988). Powiązania produkcyjno-przestrzenne zakładu przemysłowego [Production and spatial links of an industrial plant]. In: Z. Zioło (ed.). Zakład przemysłowy w akademickim kształceniu nauczycieli geografii [An industrial plant in the academic education of geography teachers]. Materiały i Sprawozdania Centralnego Ośrodka Metodycznego Studiów Nauczycielskich, 14, 79-83.

Troc, M. (1991a). Ćwiczenia z geografii przemysłu [Exercises in industrial geography]. Kraków: Wydawnictwo Naukowe Wyższej Szkoły Pedagogicznej.

Troc, M. (1991b). Kwestionariusz do badania zakładu przemysłu rolno-spożywczego [Questionnaire for the study of the agri-food industry plant]. In: Z. Zioło (ed.). Problemy przemysłu rolno-spożywczego w badaniach geograficznych [Problems of the agri-food industry in geographical surveys]. Warszawa-Kraków: COMSN, Komisja Geografii Przemysłu Polskiego Towarzystwa Geograficznego.

Turczyn, I. (1968). Załoga Kombinatu Siarkowego „Tarnobrzeg” w latach 1962-1965 [The workforce of the Sulphur Combine „Tarnobrzeg” in the years 1962-1965]. Zeszyty Badań Rejonów Uprzemysławianych Polskiej Akademii Naukowej, 29.

Turczyn-Zioło, I. (1978). Załoga Kombinatu Siarkowego i jej wpływ na przemiany struktury społecznej Tarnobrzeskiego Rejonu Uprzemysławianego [The workforce of the Sulphur Combine and its impact on the transformation of the social structure of the Tarnobrzeg Region Under Industrialisation]. Przemiany społeczno-ekonomicznego Tarnobrzeskiego Rejonu Uprzemysławianego [Socio-economic transformation of the Tarnobrzeg Region Under Industrialisation]. Warszawa: Wydawnictwo Naukowe PWN.

Winiarski, B. (1962). Na marginesie uwag S.M. Zawadzkiego [Remarks to the comments by S.M. Zawadzki]. Przegląd Geograficzny, 2.

Zawadzki, M.S. (1962). Zakład przemysłowy jako przedmiot badań ekonomiczno-geograficznych [Industrial plant as a theme of economic and geographic research]. Przeglad Geograficzny, 2.

Zioło, Z. (1971). Stan badań nad problemem struktury przestrzennej przemysłu i jej form koncentracji [The state of research on the problem of the spatial structure of industry and its forms of concentration]. Materiały Informacyjne WKPG w Rzeszowie, styczeń-marzec, 25-38.

Zioło, Z. (1976). The development of optimum territorial forms of industrial concentration. Geographia Polonica, 33.

Zioło, Z. (1987). Próba zarysu teorii struktury przestrzennej przemysłu [An attempt to outline the theory of the spatial structure of industry]. Prace Geograficzne, 112(11).

Zioło, Z. (red.) (1988a). Zakład przemysłowy w akademickim kształceniu nauczycieli geografii [The industrial plant in the academic education of geography teachers]. Materiaty i Sprawozdania Centralnego Ośrodka Metodycznego Kształcenia Nauczycieli, 16.

Zioło, Z. (1988b). Funkcjonowania i rozwój przedsiębiorstwa przemysłowego [Functioning and development of an industrial enterprise]. Materiały i Sprawozdania Centralnego Ośrodka Metodycznego Kształcenia Nauczycieli, 16.

Zioło, Z. (ed.) (1994a). Funkcjonowanie przedsiębiorstw przemysłowych w zmieniających się warunkach gospodarowania [Operation of industrial enterprises in the changing economic conditions]. Warszawa-Kraków: Centralny Ośrodek Metodyczny Studiów Nauczycielskich, Komisja Geografii Przemysłu Polskiego Towarzystwa Geograficznego, Wydawnictwo Naukowe Wyższej Szkoły Pedagogicznej w Krakowie.

Zioło, Z. (1994b). Zmiany otoczenia przedsiębiorstw przemysłowych w nowych warunkach gospodarowania [Changes in the environment of industrial enterprises in the new conditions of management]. In: Funkcjonowanie przedsiębiorstw przemysłowych w zmieniających się warunkach gospodarowania [Functioning of industrial enterprises in the changing economic conditions]. Warszawa-Kraków: Centralny Ośrodek Metodyczny Studiów Nauczycielskich, Komisja Geografii Przemysłu Polskiego Towarzystwa Geograficznego, Wydawnictwo Naukowe Wyższej Szkoły Pedagogicznej w Krakowie.

Zioło, Z. (1996). Model funkcjonowania przestrzeni geograficznej i jego znaczenie dla gospodarki przestrzennej [The model of the functioning of geographical space and its importance for spatial economy]. In: U. Wich (ed.). Gospodarka, przestrzeń, środowisko [Economy, space, environment]. Lublin: Uniwersytet Marii Skłodowskiej-Curie w Lublinie.

Zioło, Z. (1997). Miejsce struktury przestrzennej przemysłu w przestrzeni geograficznej [The place of spatial structure of industry in geographical space]. In: B. Domański (ed.). Geografia, 
Człowiek, Gospodarka [Geography, Man, Economy]. Kraków: Wydawnictwo Instytutu Geografii Uniwersytetu Jagiellońskiego, 125-132.

Zioło, Z. (2008). Problemy badawcze struktury przestrzennej przemysłu [Industrial spatial structure: research problems]. Prace Komisji Geografii Przemysłu Polskiego Towarzystwa Geograficznego [Studies of the Industrial Geography Commission of the Polish Geographical Society], 11, 9-25.

Zioło, Z. (2017). Wpływ przemysłu i usług na rozwój społeczno-gospodarczy układów przestrzennych [Impact of Industry and Services on Socio-Economic Development of Spatial Systems]. Prace Komisji Geografii Przemysłu Polskiego Towarzystwa Geograficznego [Studies of the Industrial Geography Commission of the Polish Geographical Society], 31(4), 7-24.

Zioło, Z. Rachwał, T. (ed.) (2008). Problematyka badawcza geografii przemysłu [The problems of industry research in geographic and economic sciences]. Prace Komisji Geografii Przemysłu Polskiego Towarzystwa Geograficznego [Studies of the Industrial Geography Commission of the Polish Geographical Society], 11.

Zbigniew Zioło, professor, the Pedagogical University of Cracow, Institute of Geography, the Department of Entrepreneurship and Spatial Management. He holds a DSc title. He is also a professor of Economics. His research interests include: land management, economic geography, socio-economic policies, economics and policies of regional development.

\section{Address:}

Pedagogical University of Cracow

Institute of Geography

Department of Entrepreneurship and Spatial Management

ul. Podchorążych 2, 30-084 Kraków, Poland

e-mail: zbziolo@onet.eu 